Indonesian Journal of Biotechnology, June, 2014

Vol. 19, No. 1, pp.56-63

\title{
Poly- $\beta$-Hydroxybutyrate (PHB) Production By Amylolytic Micrococcus sp. PG1 Isolated From Soil Polluted Arrowroot Starch Waste
}

\author{
Sebastian Margino ${ }^{1}$, Erni Martani ${ }^{1}$ and Andriessa Prameswara ${ }^{2}$,
}

\begin{abstract}
${ }^{1}$ Department of Agricultural Microbiology, Faculty of Agriculture, Universitas Gadjah Mada, Yogyakarta, Indonesia

2Study Program for Biotechnology, Graduate School of Universitas Gadjah Mada, Yogyakarta, Indonesia
\end{abstract}

\begin{abstract}
Poly- $\beta$-hydroxybutyrate (PHB) production from amylolytic Micrococcus sp. PG1. Poly- $\beta$-hydroxybutyrate (PHB) is an organic polymer, which synthesized by many bacteria and serves as internal energy. PHB is potential as future bioplastic but its price is very expensive due to glucose usage in PHB industry. The development of PHB production using starch as an alternative carbon source has been conducted to reduce the dependence of glucose in PHB production. In this study, amylolytic bacteria from arrowroot processing site were screened quantitavely based on amylase specific activity and PHB producing ability. The result of the study showed that among of 24 amylolytic isolates, 12 isolates of them were able to accumulate PHB ranged from $0,68-11,65 \%$ (g PHB/g cdw). The highest PHB production from substrate arrowroot starch was PG1 and after optimization resulted in increasing of PHB production up to 16,8\% (g PHB/g cdw) 40 hours incubation time. Based on morphological, biochemical and physiological characters, the PG1 isolate was identified as Micrococcus sp. PG1. Result of the FTIR analysis of produced polymer by Micrococcus sp. PG1 was indicated as poly- $\beta$ - hydroxybutyrate (PHB)
\end{abstract}

Keywords: Poly- $\beta$-hydroxybutyrate (PHB), indigenous amylolytic bacteria, arrowroot starch

\section{Introduction}

Poly- $\beta$-hydroxybutyrate (PHB) is a polymer, which naturally synthesized by many bacteria and serves as internal energy. PHB is biodegradabel and biocompatible (Chen, 2009) and its physical and chemical characteristics are similar to polypropylene (Flieger et al., 2003; Reddy et al., 2003). PHB is potential as future bioplastic but its price is very expensive due to glucose usage in PHB industry. The development of PHB production using alternative carbon source such as starch, canola industrial wastes, dairy wastes, and bit has been conducted to reduce the dependence of glucose in PHB

\section{"Corresponding author:}

Sebastian Margino. Faculty of Agriculture, Universitas Gadjah Mada, Yogyakarta, Indonesia. Email: margino@ugm.ac.id production (Koller et al., 2010). Among those, starch is potential to develop as alternative carbon source for $\mathrm{PHB}$ production because it is cheap, vary and many in supply (Koller et al., 2010; Gonzalez-Garcia et al., 2011).

Research of starch as carbon source for PHB production has been explored during years with various of bacteria. Margino et al. (2000) use tapioka starch to produce PHB by Bacillus and Pseudomonas while Yanti (2011) use sago starch and isolate Bacillus PSA 10. The results suggested that there is possibility to use other starches as carbon source for PHB production. One of alternatives is arrowroot (Maranta arundinaceae) starch which has carbon (C) content 57,69\%, nitrogen (N) content $0,33 \%$, phosphorous (P) content $0,004 \%$ and kalium (K) content $0,35 \%$.

In order to optimize arrowroot starch as carbon source in PHB production, exploitation of amylolytic bacteria which can 
also synthesize PHB is required. Hoping that by optimization measures the production of PHB from arrowroot starch be more effective and efficient. Amylolytic bacteria which can hydrolyzed arrowroot starches are potential to be found from arrowroot processing starch. Therefore, screening of indigenous amylolytic bacteria is done to get the potential isolate.

\section{Materials And Methods \\ Isolation of bacteria from starch production site}

Three different samples being liquid waste, solid waste and raw arrowroot starch were collected from arrowroot starch processing site in Sendang Sari, Kulon Progo, Yogyakarta, Indonesia. Ten grams of each samples were serially diluted in $90 \mathrm{ml}$ distilled water and placed onto arrowroot starch nutrient agar plates (Joetono et al., 1978). Cultures were incubated at room temperature for 24-72 hours. Various colonies of different morphologies were individually picked and sub cultured on nutrient agar plate added by arrowroote starch.

\section{Microorganisms screening for amylolitic activity, amylase activity and $\mathrm{PHB}$ activity}

Determination of amylolytic activity on starch agar media was based on the presence of clear zone around the bacterial colony upon flooding with $\mathrm{I}_{2} \mathrm{KI}$ solution. The hydrolytic ability value is the ratio of hydrolysis zone (clear zone) diameter $(\mathrm{cm})$ formed by a bacterium colony and its colony diameter (cm) (Jamilah et al., 2009).

Amylolytic isolates were grown in Ammonium Sulphate Starch media (Fred and Waksman, 1928) with inoculum concentration $5 \%(\mathrm{v} / \mathrm{v})$ and were incubated at agitation rate $125 \mathrm{rpm}$, temperature $30^{\circ} \mathrm{C}$ for 72 hours (Lee and Fujio, 1997). Crude enzymes were obtained by centrifugation at 4,000 rpm, temperature $4^{\circ} \mathrm{C}$ for 20 minutes. One $\mathrm{ml}$ of the crude enzyme was added to one $\mathrm{ml}$ of $2 \%$ arrowroot starch in $0.1 \mathrm{M}$ phosphate buffer
( $\mathrm{pH}$ 6.5). The mixture was then incubated at $37^{\circ} \mathrm{C}$ for 1 hour. Reaction was stopped by adding $1.5 \mathrm{ml}$ of I $\mathrm{N}$ acetic acid followed by $0.5 \mathrm{ml}$ of Lugol's iodine. Absorbance was read at $700 \mathrm{~nm}$ (Lee and Fujio, 1997). The alpha-amylase activity was calculated by (Espino and Tambalo, 1997) :

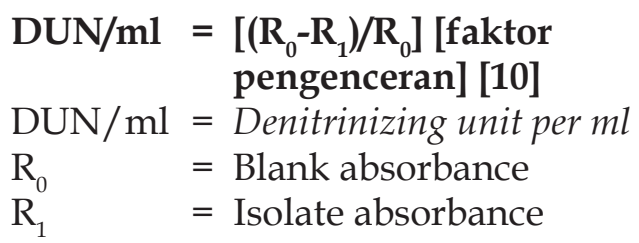

Determination of crude enzyme protein was measured by Bradford method (Bradford, 1976). The specific activity of amylase was determined by dividing the volumetric activity (DUN/ml) by the protein content $(\mathrm{mg} / \mathrm{ml})$.

Production of PHB was quantitatively measured by using Ramsay media (6.7 $\mathrm{g}$ of $\mathrm{Na}_{2} \mathrm{HPO}_{4} .7 \mathrm{H}_{2} 0 ; 1.5 \mathrm{~g}$ of $\mathrm{KH}_{2} \mathrm{PO}_{4} ; 1.0$ $\mathrm{g}$ of $\left(\mathrm{NH}_{4}\right) 2 \mathrm{SO}_{4} ; 0.2 \mathrm{~g}$ of $\mathrm{MgSO}_{4} .7 \mathrm{H}_{2} 0 ; 60$ $\mathrm{mg}$ of ferrous ammonium citrate; $10 \mathrm{mg}$ of $\mathrm{CaCl}_{2} \cdot 2 \mathrm{H}_{2} \mathrm{O}$, and $1 \mathrm{ml}$ of trace-element solution. Each liter of trace-element solution contained $0.3 \mathrm{~g}$ of $\mathrm{H}_{3} \mathrm{BO}_{3} ; 0.2 \mathrm{~g}$ of $\mathrm{CoCl}_{2} \cdot 6 \mathrm{H}_{2} 0$; $0.1 \mathrm{~g}$ of $\mathrm{ZnSO}_{4} .7 \mathrm{H}_{2} 0 ; 30 \mathrm{mg}$ of $\mathrm{MnCl}_{2} .4 \mathrm{H}_{2} 0 ; 30$ $\mathrm{mg}$ of $\mathrm{NaMoO}_{4} \cdot 2 \mathrm{H}_{2} \mathrm{O} ; 20 \mathrm{mg}$ of $\mathrm{NiCl}_{2} \cdot 6 \mathrm{H}_{2} \mathrm{O}$ and $10 \mathrm{mg}$ of $\mathrm{CuSO}_{4} \cdot 5 \mathrm{H}_{2} 0$ )(Ramsay et al., 1990) with arrowroot starches as carbon sources $1 \%(\mathrm{w} / \mathrm{v})$, inoculum concentration $5 \%(\mathrm{v} / \mathrm{v})$, temperature $30^{\circ} \mathrm{C}, \mathrm{pH} 7$, agitation rate $125 \mathrm{rpm}$ and incubation time 72 hours. The culture then subjected to centrifugation for 20 minutes at 3,000 rpm (Hahn et al., 1995). Extraction of PHB from bacteria cells was done by N-hexane acetone-diethyleter method (Senior et al., 1972). Pellet then were changed to crotonic acid by adding $3 \mathrm{ml}$ of sulfuric acid and boiled it at $100^{\circ} \mathrm{C}$ for 10 minutes. The PHB content was measured by U.V. spectrophotometer at $235 \mathrm{~nm}$.

\section{Growth optimization}

The selected isolate was optimized for PHB fermentation condition in terms of 
inoculum concentration $(2.5 ; 5 ; 10 ; 15 \%(\mathrm{v} / \mathrm{v}))$, nutrients concentrations such as arrowroot starch $(2.5 ; 5 ; 10 ; 20$ and $30 \mathrm{~g} / 1),\left(\mathrm{NH}_{4}\right)_{2} \mathrm{SO}_{4}(0$; $0.5 ; 1 ; 1.5$ and $2 \mathrm{~g} / 1), \mathrm{Na}_{2} \mathrm{HPO}_{4} .7 \mathrm{H}_{2} \mathrm{O}(0 ; 2.3$; $4.5 ; 6.7$ and $8.9 \mathrm{~g} / 10)$ and $\mathrm{KCl}(0 ; 0.5 ; 1 ; 1.5$; $2 \mathrm{~g} / \mathrm{l})$; and environmental condition such as $\mathrm{pH}(5 ; 6 ; 7$ and 8$)$, incubation temperature (30; 37 and $\left.40^{\circ} \mathrm{C}\right)$ and agitation rate $(75 ; 100 ; 125$ and $150 \mathrm{rpm})$. All optimization parameters were observed in shake flask culture.

\section{PHB production in fermentor (batch)}

The production of PHB by selected isolate was carried out in 21 fermentor with a 1.51 working volume. The best condition from optimization steps was applied. The agitation rate and temperature was maintained stable. $\mathrm{pH}$ of the medium was checked before inoculation. Aeration for this condition was 1.61/minute. Samples were withdrawn aseptically at 4 hourly intervals. PHB concentration, cell dry weight (cdw), glucose level and residual starch was observed.

\section{Genus of selected isolate identification and FTIR analysis of the polymer}

The selected isolate was further identified based on morphology, biochemical and physiological characteristics (Joetono et al., 1980). The characters was compared with characters in Bergey's Manual of Determinative Bacteria $9^{\text {th }}$ (Holt et al., 1994).

The polymer produced by the selected isolate was extracted by incubated cell mass with $\mathrm{H}_{2} \mathrm{O}_{2} 5 \%(\mathrm{v} / \mathrm{v})$ and chloroform (1:1) for 2 hours. Pellet was harvested by centrifugation 4,000 rpm for 20 minutes. The bottom part of supernatant was pour on the petri dish to let the chloroform evaporate. The extracted polymer was analyzed by Fourier Transform Infrared spectroscopy (FTIR).

\section{Results and Discussion \\ Isolation and screening of amylolytic bacteria producing $\mathrm{PHB}$}

Twenty four amylolitic bacteria were isolated from arrowroot processing site. Twelve among them which had hydrolytic ability ranging from 2.50-6.00 were screening for amylase activity and PHB production (Table 1). The amylase specific activity ranges from 111.85-2121.52 DUN/mg and PHB productivity capacity ranged from $0.68-11.65 \%$ (g PHB/g cdw) for those isolates. Based on this data, PG1 was chosen as the most potential isolate. It has amylolytic activity $2121,52 \mathrm{DUN} /$ $\mathrm{mg}$ and PHB production $11.65 \%$.

\section{Growth optimization}

The best conditions for PHB production by the isolate PG1 was achieved at 5\% (v/v)

Table 1. Hydrolytic ability, amylase activity and PHB production of several amylolytic isolates from arrowroot processing site

\begin{tabular}{|c|c|c|c|c|c|c|c|}
\hline $\begin{array}{l}\text { Isolate } \\
\text { code }\end{array}$ & $\begin{array}{l}\text { Hydrolytic } \\
\text { ability }\end{array}$ & $\begin{array}{l}\text { Amylase } \\
\text { activity } \\
\text { (DUN/ml) }\end{array}$ & $\begin{array}{c}\text { Protein } \\
\text { content (mg/ } \\
\mathrm{ml})\end{array}$ & $\begin{array}{l}\text { Spesific Activity of } \\
\text { Amylase (DUN/mg } \\
\text { protein) }\end{array}$ & $\begin{array}{l}\text { PHB } \\
\text { content } \\
(\mathrm{g} / 1)\end{array}$ & $\begin{array}{l}\text { Cell dry } \\
\text { weight } \\
(\mathrm{g} / \mathrm{l})\end{array}$ & PHB (\%) \\
\hline ABG 21 & 3.08 & 86.59 & 0.272 & 318.18 & 0.0134 & 0.58 & $2.31^{\mathrm{a}}$ \\
\hline ABG 22 & 3.20 & 86.64 & 0.319 & 271.55 & 0.0050 & 0.69 & $0.72^{\mathrm{a}}$ \\
\hline AG 3 & 2.54 & 24.56 & 0.169 & 145.28 & 0.0085 & 0.80 & $1.06^{\mathrm{a}}$ \\
\hline AG 4 & 5.95 & 30.26 & 0.163 & 186.03 & 0.0078 & 0.38 & $2.08^{\mathrm{abc}}$ \\
\hline AG 7 & 3.66 & 27.07 & 0.143 & 189.35 & 0.0147 & 0.68 & $2.16^{\mathrm{ab}}$ \\
\hline AG 8 & 3.16 & 46.34 & 0.154 & 300.80 & 0.0118 & 0.52 & $2.29^{a b c}$ \\
\hline LC 32 & 3.k11 & 86.90 & 0.297 & 292.86 & 0.0090 & 1.33 & $0.68^{\mathrm{a}}$ \\
\hline PG 8 & 3.5 & 16.23 & 0.145 & 111.85 & 0.0398 & 0.76 & $5.23^{\mathrm{de}}$ \\
\hline PG 1 & 3.71 & 95.74 & 0.045 & $2,121.52$ & 0.0816 & 0.70 & $11.65^{g}$ \\
\hline PG 4 & 4.48 & 89.77 & 0.200 & 448.80 & 0.0130 & 0.67 & $1.96^{\mathrm{ab}}$ \\
\hline PG 5 & 3.54 & 89.94 & 0.081 & 1106.31 & 0.0120 & 0.57 & $2.09^{\mathrm{ab}}$ \\
\hline PG 6 & 2.57 & 24.05 & 0.144 & 167.53 & 0.1025 & 1.29 & $7.98^{\mathrm{f}}$ \\
\hline
\end{tabular}




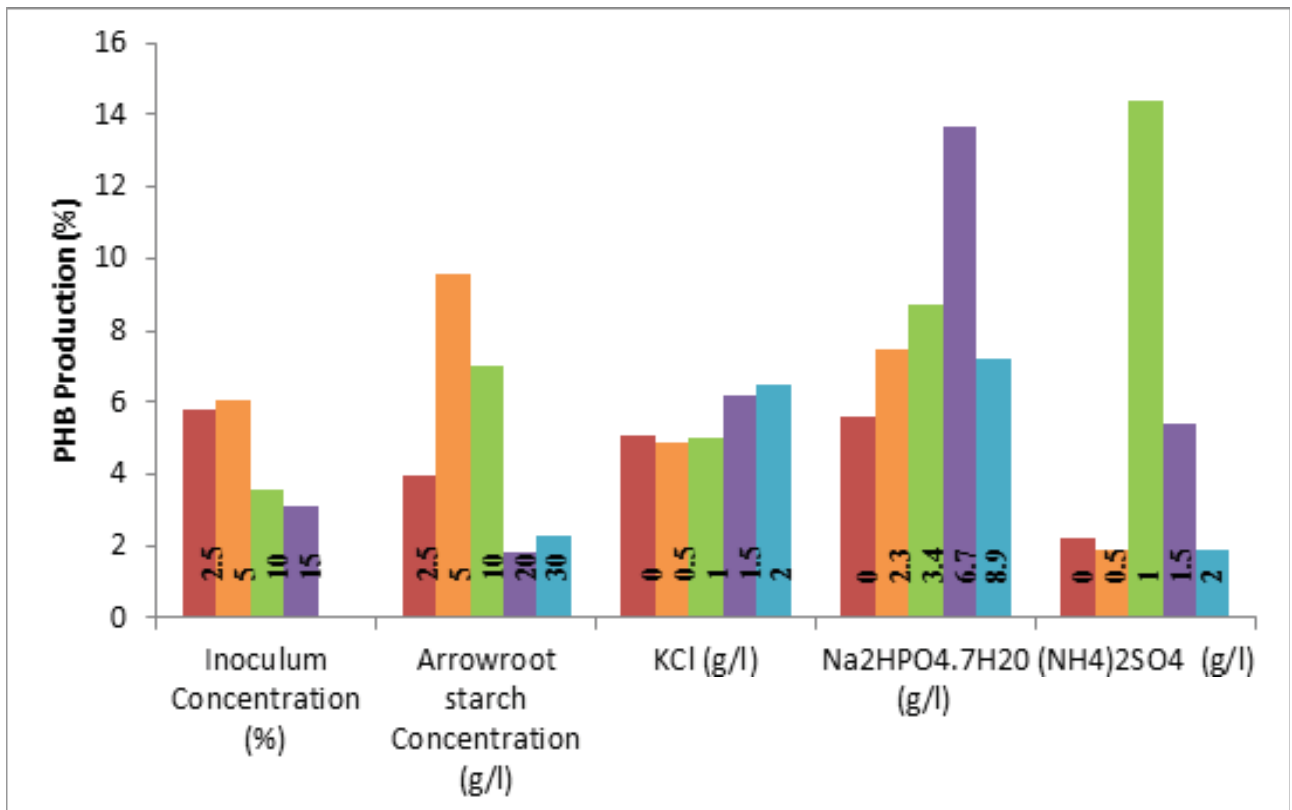

Figure 1. Effect of inoculum and nutrient concentration on PHB production

inoculum concentration, arrowroot starch at $5 \mathrm{~g} / 1,\left(\mathrm{NH}_{4}\right)_{2} \mathrm{SO}_{4} 1 \mathrm{~g} / 1, \mathrm{Na}_{2} \mathrm{HPO}_{4} .7 \mathrm{H}_{2} 06,7 \mathrm{~g} / 1$ and $\mathrm{KCl} 2 \mathrm{~g} / 1$ (Figure 1). Whereas the best environmental condition in term of initial $\mathrm{pH}$ at 7 , temperature at $30^{\circ} \mathrm{C}$ and agitation speed at $125 \mathrm{rpm}$ (Figure 2). After optimization, PHB production of PG1 was increased from 11,65 to $16,8 \%$.

PG1 isolate had the highest rate of $\mathrm{PHB}$ production by $6 \%$ at inoculum concentration $5 \%$ (Figure 1). Inoculum concentration is important to be studied because inoculum concentrations affect the efficiency of PHB production and the incubation time (Yamane et al., 1996; Cetin et al., 2006). While for the nutrient concentration, all parameters were similar with the standart Ramsay's medium, except the $\mathrm{KCl}$ concentration. PG1 achieved 9.6\% PHB when used $5 \mathrm{~g} / 1$ arrowroot starch, and respectively $13.7 \%$ and $14.4 \%$ of PHB with $6.7 \mathrm{~g} / 1 \mathrm{Na}_{2} \mathrm{HPO}_{4} \cdot 7 \mathrm{H}_{2} 0$ and $1 \mathrm{~g} / 1$ $\left(\mathrm{NH}_{4}\right)_{2} \mathrm{SO}_{4}$. For the $\mathrm{K}$ component, PG1 isolate required $2 \mathrm{~g} / 1 \mathrm{KCL}$ to get the best production of PHB. It was suggested that PG1 isolate required more $\mathrm{K}$ for $\mathrm{PHB}$ production.

The effect of temperature was studied to find out the best temperature to support production PHB by PG1. PG1 required incubation temperature at $37^{\circ} \mathrm{C}$ to achieved $12 \%$ of PHB. Shi et al. (2001) mentioned that incubation temperature at $37^{\circ} \mathrm{C}$ significantly induced the expression of gene which responsible for $\mathrm{PHB}$ production. Bacillus megaterium PSA 10 also need incubation temperature at $37^{\circ} \mathrm{C}$ for the $\mathrm{PHB}$ production (Yanti, 2011).

PG1 produced $14.9 \%$ PHB when incubated with agitation rate $125 \mathrm{rpm}$. Agitation rate below and above $125 \mathrm{rpm}$ caused a decrease in PHB production, suggest that this agitation rate served the best condition for PG1 in using starch as carbon source for growth and PHB production.

In terms of initial $\mathrm{pH}$, our result (Figure 2) showed consintency with Palleroni and Palleroni (1978) who recommended a $\mathrm{pH}$ range of 6.0 to 7.5 for microbial growth and PHB production. Wei et al. (2011) also showed the best $\mathrm{PHB}$ production by Cupriavidus taiwanensis at initial pH 7. PG1 achieved the best PHB production by $16.8 \%$ at initial $\mathrm{pH} 7$.

\section{Production of PHB in fermentor}

Optimization result showed that PG1 isolate could produce highest PHB $37 \mathrm{mg} / \mathrm{L}$ and cell dry weight $850 \mathrm{mg} / \mathrm{L}$, respectivelly, 


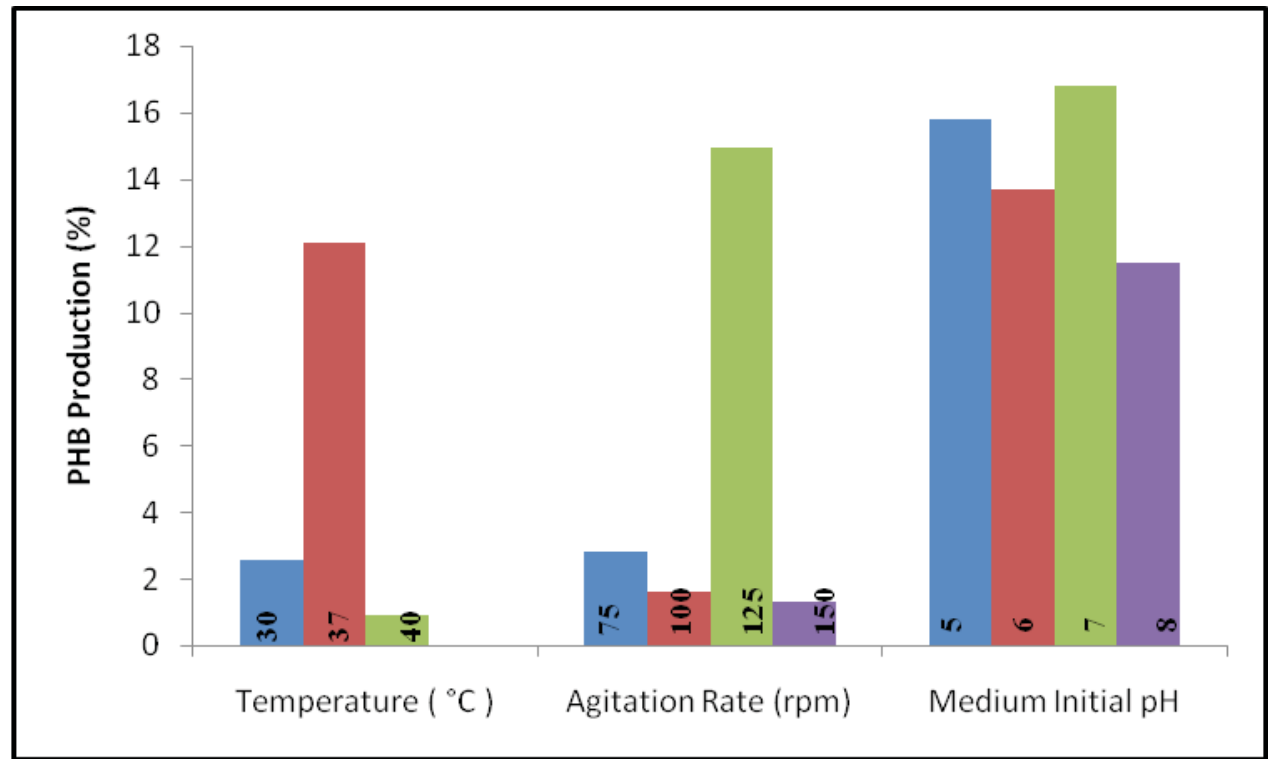

Figure 2. Effect of environmental condition on PHB production

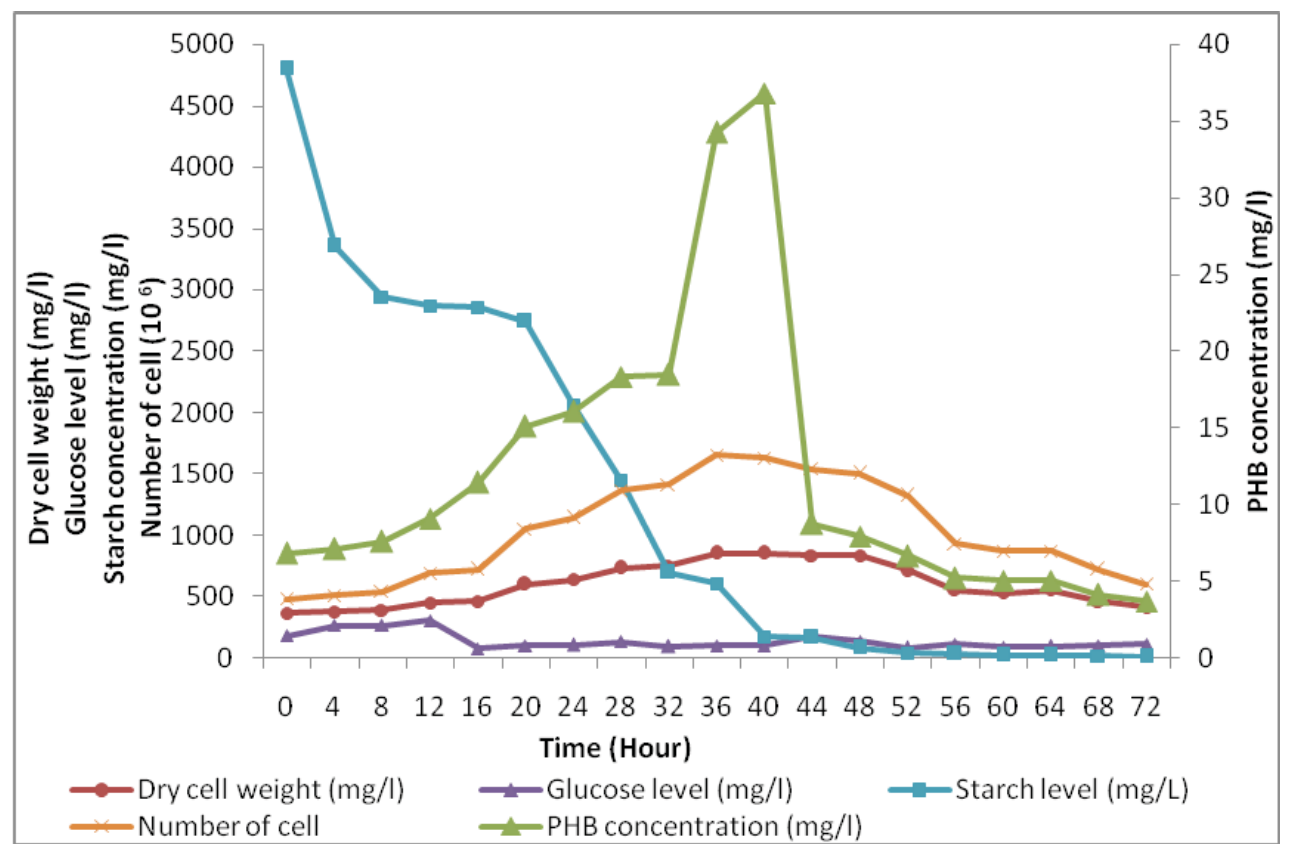

Figure 3. Time course of PHB production by Micrococcus sp. PG1

for 40 hours incubation time (Figure 3 ). The PHB production sharply increase when the level of starch was sharply decrease. This condition was linear with (Anderson \& Dawes, 1990) that mentioned the production of PHB occurred when the nutrients is unbalanced because of the lack of carbon source. This result showed that PG1 synthesized PHB since exponential phase. PHB production during exponential phase means the PHB production is growth associated (Lee, 1996; Grothe et al., 1999).

\section{Identification of PGI Isolate}

Based on the morphological, biochemical, and physiological characters 


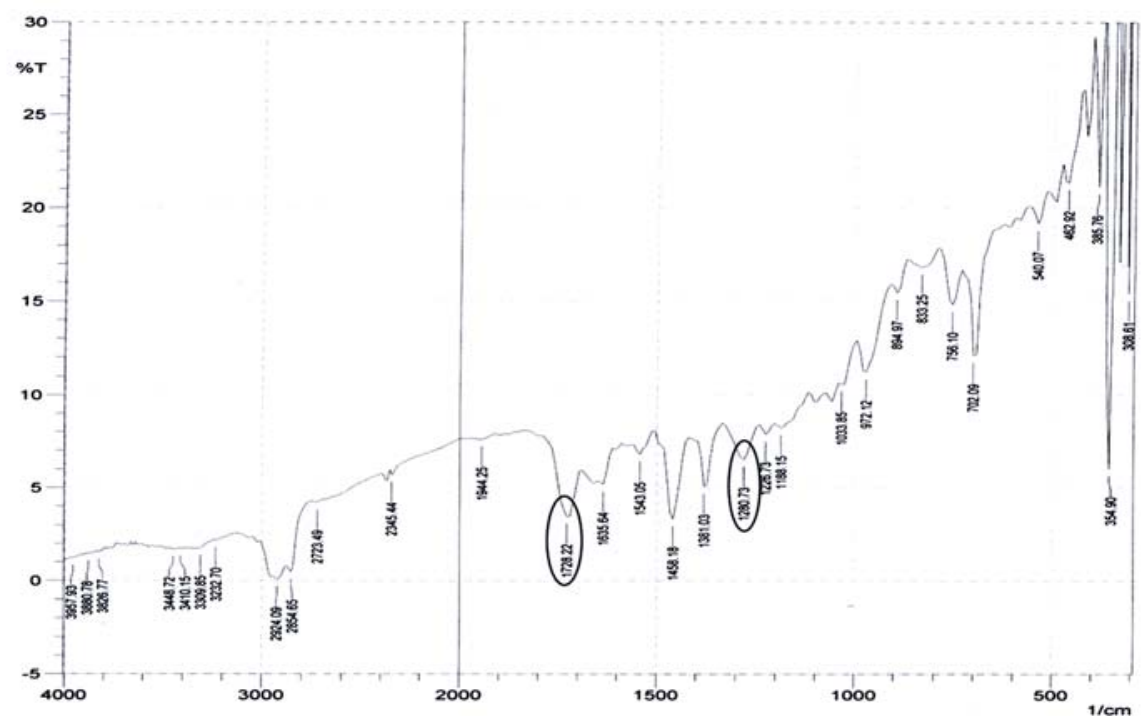

(a)

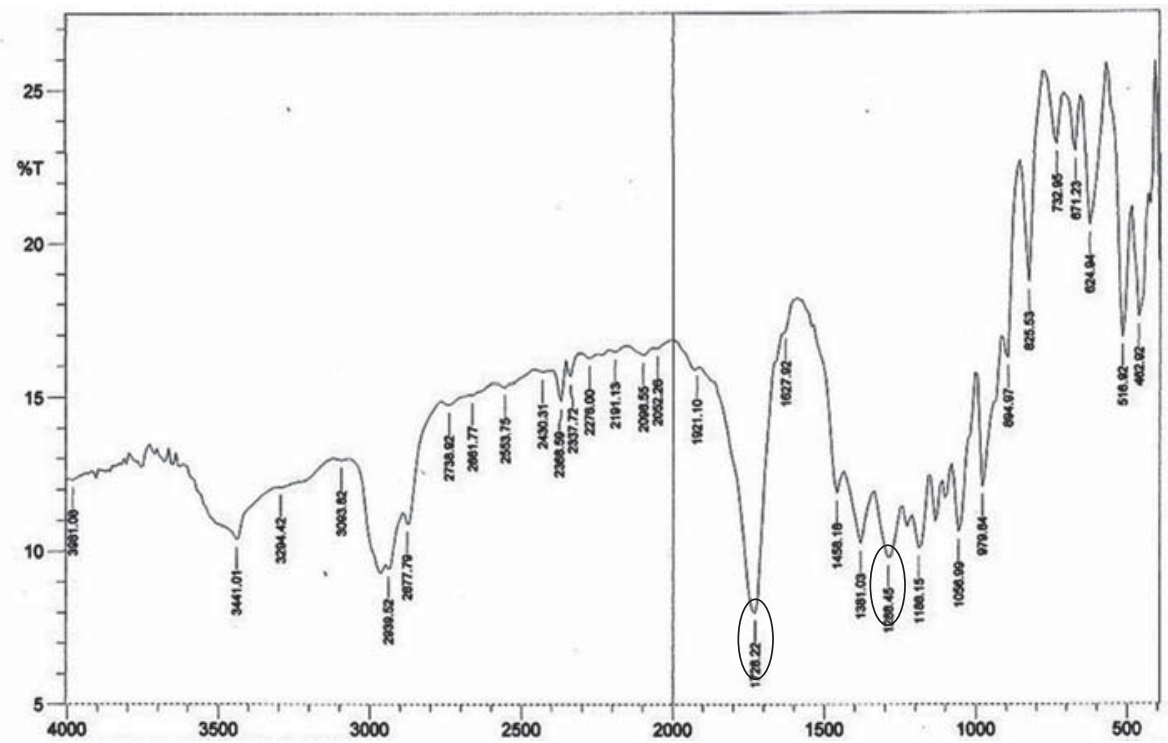

(b)

Figure 4. FTIR spectroscopy of the extracted polymer synthesized by PG1 (a) and PHB standard (b)

PGI isolate was identified as Micrococcus sp. PG1 (data unpublished).

\section{FTIR analysis}

FTIR analysis of polymer produced by PG1 using arrowroot starch as subtrates was investigated along with $\mathrm{PHB}$ obtained from commercial source (Sigma). FTIR spectra of the extracted polymer showed the intense peaks $1728.22 \mathrm{~cm}^{-1}$ and $1280.73 \mathrm{~cm}^{-1}$ corresponding to specific rotations around carbon atoms specific to certain functional groups (Figure 4). The peak at $1728.22 \mathrm{~cm}^{-1}$ corresponds to ester carbonyl $(\mathrm{C}=\mathrm{O})$ stretch of the ester group present in the molecular chain of highly ordered crystalline structure. The peak of at $1280.73 \mathrm{~cm}^{-1}$ corresponds to $-\mathrm{CH}$ group (Figure 4). These peaks are corresponding to the peaks obtained for the standard PHB (Sigma) at $1728.22 \mathrm{~cm}^{-1}$ and $1280.73 \mathrm{~cm}^{-1}$ 
exactly confirming that the extracted polymer was poly- $\beta$-hydroxubutyrate (PHB) (Hong et al., 1999).

\section{Conclusion}

The best condition for PHB production by the isolate PG1 was achieved at $5 \%(\mathrm{v} / \mathrm{v})$ inoculum concentration, arrowroot starch 5 $\mathrm{g} / \mathrm{l}(\mathrm{w} / \mathrm{v}),\left(\mathrm{NH}_{4}\right)_{2} \mathrm{SO}_{4} 1 \mathrm{~g} / 1, \mathrm{Na}_{2} \mathrm{HPO}_{4} \cdot 7 \mathrm{H}_{2} \mathrm{O}$ $6,7 \mathrm{~g} / 1$ and $\mathrm{KCl} 2 \mathrm{~g} / 1$; whereas the best environmental conditions in term of initial $\mathrm{pH}$ was 7 , temperature $37^{\circ} \mathrm{C}$ and agitation speed $125 \mathrm{rpm}$. Optimization of PG1 resulted in increasing of $\mathrm{PHB}$ production up to $16.8 \%$ (g PHB/g cdw) for 40 hours incubation time. FTIR analysis of the polymer indicated that produced polymer by Mirococcus sp. PG1 was a poly- $\beta$-hydroxybutirate.

\section{Acknowledgement}

This research was funded by "Hibah Kompetensi" under the Minister of National Education, Republic of Indonesia under the PI: Prof. Ir. Sebastian Margino, Ph.D.

\section{References}

Anderson, A.J. and Dawes, E.A. 1990. Occurrence, Metabolism, Metabolic Role and Industrial Uses of Bacteria Polyhydroxyalkanoates. Microbiol Rev 54 (4) : 450-472.

Bradford, M.M. 1976. A Rapid and Sensitive Methode for Quantification of Microgram Quantities of Protein Utilizing the Principle of Protein-dye Binding. Anal Biochem 72: 248-254.

Bryom, D. 1987. Polymer Synthesis by Microorganisms: Technology and Economics. Tibtech 5: 246-250.

Cetin, D., Gunduz, U., Eroglu, I., Yucel, M \& Turker, L. 2006. Poly- $\beta$-hydroxybutyrate Accumulation and Releasing by Hydrogen Producing Bacteria, Rhodobacter sphaeroides O.U.001. A Transmission Electron Microscopic Study. Afr J Biotechnol 5: 2069-2072.

Chen, G.Q. 2009. A Microbial Polyhydroxyalkanoates (PHA) Based
Bio- and Materials Industry. Chem Soc Rev 38: 2434-2446.

Espino, T.M. and Tambalo, R.D. 1997. Isolation, Screening and Characterization of High Yielding a-Amylase Producing Bacteria. Annual Reports of IC Biotechnology 20: 744-754.

Flieger, M., Kantorova, M., Prell, A., Rezanka, T. \& Votruba, J. 2003. Biodegradable Plastics from Renewable Sources. Folia Microbiol 48 (1) : 27-44.

Fred, E.B. and Waksman, S.A. (1928) Laboratory Manual of General Microbiology. McGrawHill Book, New York.

Gonzalez-Garcia, Y., Rosales, M.A., GonzalezReynoso, O., Sanjuan-Denas, R. and Cordiva, J. 2011. Polyhydroxybutirate production by Saccharophagus degradans using raw starch as carbon source. Eng Life Sci 11 (1) : 59-64.

Grothe, E., Young, M. and Chisti, Y. 1999. Fermentation Optimization for the Production of Poly( $\beta$-hydroxybutyric acid) Microbial Thermoplastic. Enzyme Microb Tech 25: 132-141.

Hahn, S.K., Chang, Y.K. and Lee, S.Y. 1995. Recovery and Characterization of Poly(3hydroxybutyric acid) in Alcaligenes eutrophus and Recombinant Escherichia coli. Appl Environ Microbiol 61 (1) : 34-39.

Holt, J.G., Krieg, N.R., Sneath, P.H.A., Stanley, J.T. and Williams, S.T. 1994. Bergey's Manual of Determinative Bacteriology. $9^{\text {th }}$ ed. Lipincot, Williams and Wilkins, Baltimore.

Hong, K., Sun, S., Tian, W., Chen, G.Q. and Huang W. 1999. A Rapid Method for Detecting Bacterial Polyhydroxyalkanoates in Intact Cell by Fourier Transform Infrared Spectroscopy. Appl Microbiol Biotechnol $51: 523-526$.

Jamilah, I.T., Meryandini, A., Rusmana, I., Suwanto, A and Mubarik, N. R. 2009. Activity of Proteolytic and Amylolitic Enzymes from Bacillus spp. Isolated from Shrimp Ponds. Microbiol Indones 3 (2) : 67-71. 
Margino et al.

Joetono, Soedarsono, S., Hartadi, S., Kabirun, S., Darmosuwito, S. and Soesanto. (1978) Pedoman Praktikum Mikrobiologi untuk Perguruan Tinggi. Departemen Pertanian, Fakultas Pertanian, UGM. Yogyakarta.

Koller, M., Atlic, A., Dias, M., Reiterer, A. and Braunegg, G. (2010) Microbial Polyhydroxyalkanoates Production from Waste Raw Materials. In: Chen, G.Q. 2010. Plastics from Bacteria: Natural Functions an Applications. Springer, Munster.

Law, J.H. and Slepecky, R. A. 1961. Assay of Poly- $\beta$-Hydroxybutyric Acid. J Bacteriol 82 (1) : 33-36.

Lee, A.C. and Fujio, Y. 1997. Amylolytic Activities of Fungal Isolates from Banh Men, a Fermentation Starter from Vietnam. Annual Reports of IC Biotechnology 20 : 155163.

Lee, S.Y. 1996. Plastic Bacteria? Progress and Prospect for Polyhydroxyalkanoate Production in Bacteria. Trends Biotechnol 14 (11): 431-438.

Margino, S., Martani, E., Soesanto, Yuswanto, A. and Sembiring, L. 2000. Isolasi dan Seleksi Bakteri Penghasil Plastik Terdegradasi, Poli- $\beta$-Hidroksibutirat. Biologi 2(10): 583-597.

Palleroni, N.J. and Palleroni, A.V. 1978. Alcaligeneslatus, a New Species of Hydrogen-Utilizing Bacteria. Int J of Syst Bacteriol 28 : 416-424.

Ramsay, B.A., Lomaliza, K.,Chavaric, C., Dube,B.,Bataille, P. and Ramsay, J.A. 1990. Production of Poli- $\beta$-hidroxybutyricCo-hydroxyvaleric Acids. Appl Environ Microbiol 56:2093-2098.

Reddy, C.S.K., Ghai, R., Rashmi and Kalia V.C. 2003. Polyhydroxyalkanoates: An Overview. Bioresource Technol 87 : 137146.

Reddy,S.V., Thirumala, M., Reddy, T.V.K. and Mahmood, S.K. 2008. Isolation of Bacteria Producing Polyhydroxyalkanoates (PHA) from Muncipal Sewage Sludge. World J Microbiol Biotechnol 24 : 2949-2955.

Senior, P.J., Beech, G.A., Ritchie, G.A.F. and Dawes, E.A. 1972. The Role of
I.J. Biotech.

Oxygen Limitation in the Formation of Poly- $\beta$-hydroxybutyrate during Batch and Continous Culture of Azotobacter beijerincki. Biochem J 128 : 1193-1201.

Shi, H., Kyuwa, K. Takasu, M. and Shimizu, K. 2001. Temperature Induced Expression of phb Genes in Escherichia coli and the Effect of Temperature Patterns on the Production of Poly-3-hydroxybutyrate. J Biosci Bioeng 91 (1) : 21-26.

Yanti, N.A. 2011. Kajian Bakteri Amilolitik Penghasil Poli- $\beta$-hidroksibutirat dari Pati Sagu. Disertation. Faculty of Biology, University of Gadjah Mada. Yogyakarta. 